The Gender of Memory 


\section{ASIA PACIFIC MODERN}

Takashi Fujitani, Series Editor

1. Erotic Grotesque Nonsense: The Mass Culture of Japanese Modern Times, by Miriam Silverberg

2. Visuality and Identity: Sinophone Articulations across the Pacific, by Shu-mei Shih

3. The Politics of Gender in Colonial Korea: Education, Labor, and Health, 1910-1945, by Theodore Jun Yoo

4. Frontier Constitutions: Christianity and Colonial Empire in the Nineteenth-Century Philippines, by John D. Blanco

5. Tropics of Savagery: The Culture of Japanese Empire in Comparative Frame, by Robert Thomas Tierney

6. Colonial Project, National Game: A History of Baseball in Taiwan, by Andrew D. Morris

7. Race for Empire: Koreans as Japanese and Japanese as Americans during World War II, by T. Fujitani

8. The Gender of Memory: Rural Women and China's Collective Past, by Gail Hershatter

9. A Passion for Facts: Social Surveys and the Construction of the Chinese Nation State, 1900-1949, by Tong Lam 


\title{
The Gender of Memory
}

Rural Women and China's Collective Past

\author{
Gail Hershatter
}

目

UNIVERSITY OF CALIFORNIA PRESS

Berkeley Los Angeles London 
University of California Press, one of the most distinguished university presses in the United States, enriches lives around the world by advancing scholarship in the humanities, social sciences, and natural sciences. Its activities are supported by the UC Press Foundation and by philanthropic contributions from individuals and institutions. For more information, visit www.ucpress.edu.

University of California Press

Berkeley and Los Angeles, California

University of California Press, Ltd.

London, England

(C) 2011 by The Regents of the University of California

\section{Library of Congress Cataloging-in-Publication Data}

Hershatter, Gail.

The gender of memory : rural women and China's collective past / Gail Hershatter.

p. $\quad$ cm. - (Asia Pacific modern ; 8)

Includes bibliographical references and index. ISBN 978-0-520-26770-1 (cloth : alk. paper)

1. Rural women-China-Shaanxi Sheng-Social conditions.

2. Rural women-China-Shaanxi Sheng-Economic conditions.

3. Socialism-China-Shaanxi Sheng-History. I. Title. HQ1769.S433H47 2011

$305.48^{\prime} 89510514309045-\mathrm{dc} 22$

2010052235

Manufactured in the United States of America

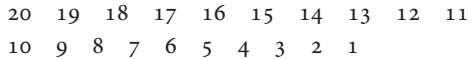

This book is printed on Cascades Enviro 100, a 100\% post consumer waste, recycled, de-inked fiber. FSC recycled certified and processed chlorine free. It is acid free, Ecologo certified, and manufactured by BioGas energy. 


\section{For Gao Xiaoxian}


